\title{
The role of perceived parenting styles and borderline personality disorder in cyberbullying: role mediator of empathy
}

\author{
Touraj Hashemi ${ }^{1}$, Rahim Badri ${ }^{2}$, Faroogh Esmaeilpour ${ }^{3}$ \\ 1.Professor of Psychology, Educational psycholog, University of Tabriz, Tabriz, Iran \\ 2.Associate Professor of Psychology, Educational psycholog, University of Tabriz, Tabriz, Iran \\ 3. Master Student of Educational Psychology, Psychology Department, University of Tabriz, Tabriz, Iran
}

\begin{abstract}
Introduction: cyberbullying is a kind of aggression, deliberate action by a group or individual using electronic communication methods, is defined repeatedly and over time against a victim who can not easily defend himself.

Aim: The purpose of this study was to determine the role of perceived parenting styles (authoritarian, authoritative, disregarded, and easy) and borderline personality disorder in cyberbullying through mediating role of empathy.

Method: The tools used in this study included: Lopez's cyberbullying questionnaire, Naghashan's parenting style questionnaire, questionnaire of borderline personality disorder, the empathy questionnaire of Baron-Cohen and Will Wright. The sample consisted of 305 high school male students of Tabriz, who were chosen according to multi-stage cluster sampling method.
\end{abstract}

Results: Path analysis results showed that perceived parenting (Authoritarian, authoritative, indifferent) and borderline personality disorder mediated by empathy can explain the cyberbullying changes.

Conclusion: Based on these findings, it can be concluded that cyberbullying can be a reflection of perceived personality disorder and perceived child abusive, dispassionate, and also low level of empathy.

KeyWords: Parenting, borderline personality, Cyberbullying, empathy 


\title{
نقش سبكهاى فرزند يرورى ادراكشده و اختلال شخصيت مرزى در قلدرى سايبرى: نقش ميانجى همدلى
}

\author{
تورج هاشمى'، رحيم بدرى تر ترى"، فاروق اسماعيل يورَ

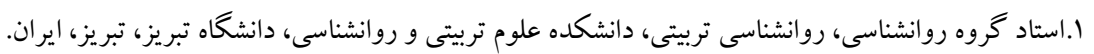

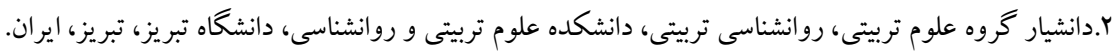

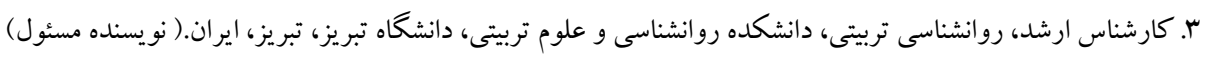

جكيده

مقدمه: قلدرى سايبرى نوعى برخاشخرى، عمل عمدى توسط يك گروه و يا فردى با استفاده از روشهاى ارتباطى الكترونيكى،

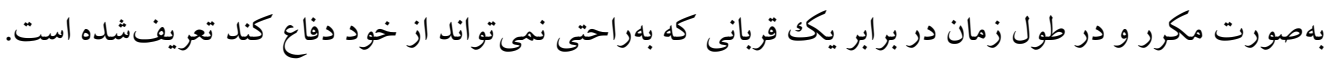
هدف: لذا يُزوهش حاضر باهدف تعيين نقش سبككهاى فرزند يرورى ادراككشده (مستبدانه، مقتدرانه، بىاعتنا و سهل گيرانه) و

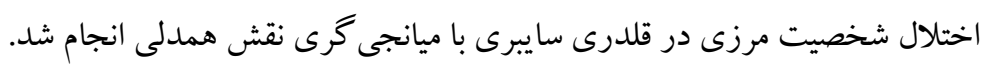
روش: مطالعه حاضر با توجه به اهداف تحقيق، از نوع همبستخى و با توجه به روش جمع آورى دادها از نوع تحقيقات توصيفى هست. ابزارهاى مورداستفاده در اين ئزوهش عبارت بودند: يرسشنامه قلدرى سايبرى لويز، برسشنامه سبككهاى فرزند يرورى

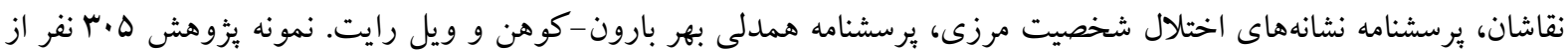

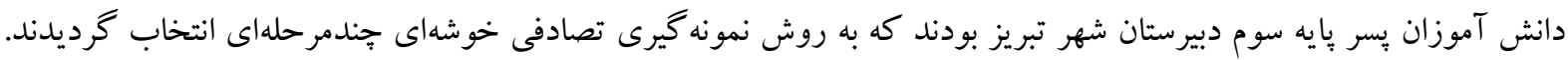

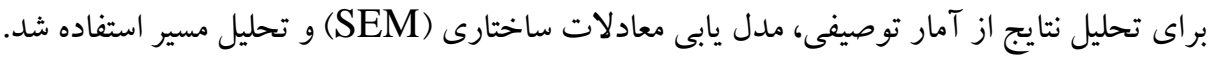

يافتها: نتايج تحليل مسير نشان داد كه فرزند يرورى ادراككشده (مستبدانه، مقتدرانه و بىاعتنا) و اختلال شخصيت مرزى با ميانجى گرى همدلى قادرند در قالب روابط ساختارى تغييرات قلدرى سايبرى را بهطور معنىدارى تبيين كنند. نتيجه كيرى: بر اساس اين يافتها مىتوان نتيجه گرفت كه قلدرى سايبرى مى تواند بازتابى از اختلال شخصيت مرزى و فرزند يرورى ادراككشه مستبدانه، بىاعتنا و همجنين بايين بود سطح همدلى باشد. كليد وازهها: فرزند يرورى، شخصيت مرزى، قلدرى سايبرى، همدلى 
يكك نوع قلدرى است كه بهوسيله اعمال تهاجمى با استفاده از فنّاورىهاى الكترونيكى به مرحله ظهور مىرسد (استاكديل، كوين، نلسون و اريكسون؛

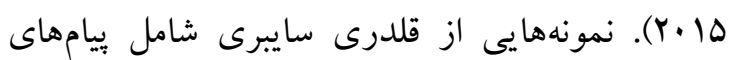
آزاردهنده، بخش شايعات اينترنتى و يا از طريق وبسايت رسانهاى اجتماعى، ارسال و ويرايش

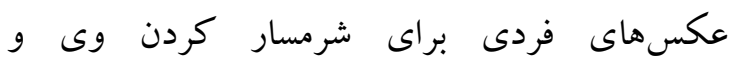
اظهارنظرهاى تحقير آميز در مورد افراد در سايتهاى

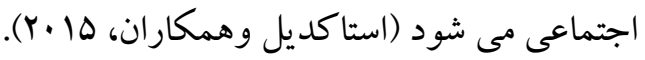
سؤال مهمى كه در اين خصوص مطرح است اين است كه جرا نوجوانان مرتكب قلدرى سايبرى مىشود؟ بر اساس الخوى تعاملى شخص، فرايند، بافت و زمان در نظريه سيستمى زيستى - بومشناسى'، رشد كود كان و

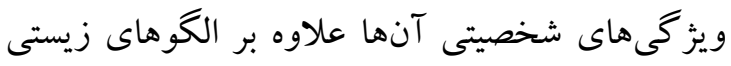
از تعاملات روزمره نيز، تأثير مىيذيرد (برون فنبرنر و و

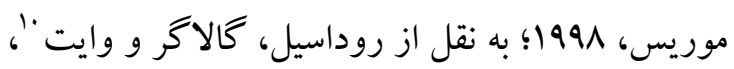

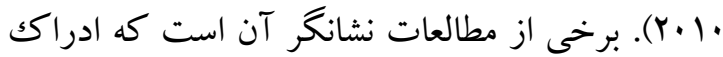

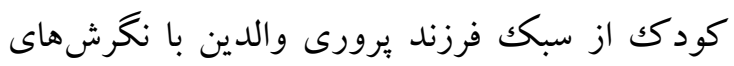
خود والدين در مورد سبككهايشان متفاوت است. بر

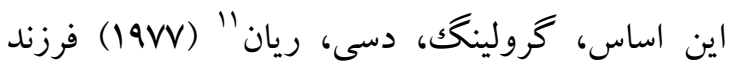
يرورى ادراكشده را بر سه بعد دانستهاند: بعد (مشار كت) كه به معناى توجه مثبت والدين به كودك و ميزان وقتى است كه براى او مى گذارند و بهطور فعال در فعاليتهاى روزانه با او مشاركت مى كنند و از آنها آكاهاند؛ بعد (احمايت از خود بيروى") كه به معناى ارزش قائل شدن والدين به ديد آناه فرزند و استفاده

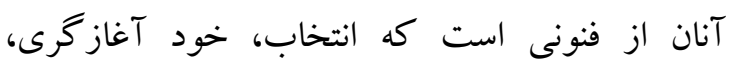
تصميم كيرى و حل مسئله را در كودكى تقويت مى كند؛ و در نهايت بعد ("مهرورزى)" كه به معناى

\footnotetext{
${ }^{8}$.Stockdale, Coyne,Nelson \& Erickson

${ }^{9}$. bioecological systems theory

${ }^{10}$. Bronfenbrenner \& Morris; Rudasill, Gallagher \& White

${ }^{11}$. Grolnick, Deci, \& Ryan
}

مقدمه

دوره نوجوانى به دليل تغييرات سريع رشدى و عاطفى،

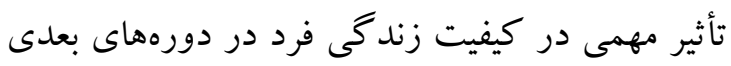
رشد دارد. اين تغييرات در بسيارى از موارد موجب

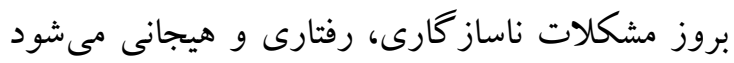
(موروى وزو واكك'، 11) ساز گارى دوره نوجوانى قلدرى 'rاست. توجه به بديده قلدرى در سطح جهانى، اولين بار با ثئوهش الويوس

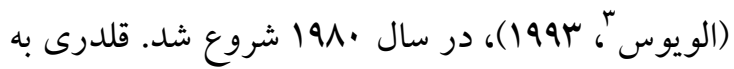
عنوان رفتارهاى برخاشخرانه و مكرر كه توسط فرد قلدر در برابر همسالان ضعيفتر انجام مىشود، تعريفشده است. (الويوس، سول1). در سالهاى اخير با تغيير سبك زندگى افراد و ورود تكنولوزى به اله زندكىها، شيوه بروز قلدرى نيز تغييريافته است. در قرن

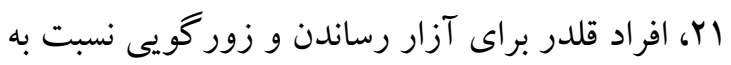
همسالانشان از شيوههاى جديدترى جون مزاحمت هاى برى تلفنى يا انتشار بيامها و تصاوير اينترنتى استفاده

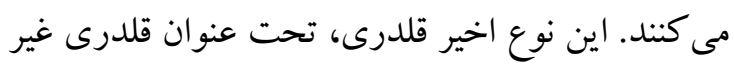

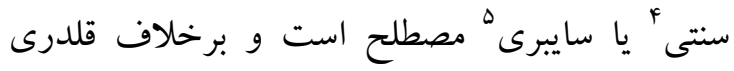
سنتى بر ارتباط جهره به جهره بين قلدر و قربانى وابسته

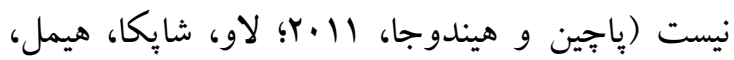

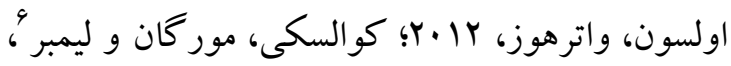

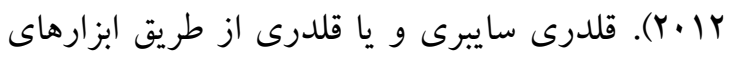
الكترونيكى كه در آن، فرد قربانى امكان دفاع از خود را ندارد، به طور فزايندهاى در جامعه امروزى رايج شده است. اين نوع قلدرى كاهى اوقات بهعنوان برخاشخرى

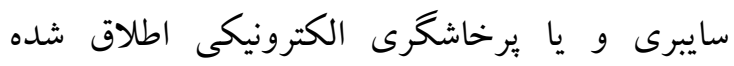

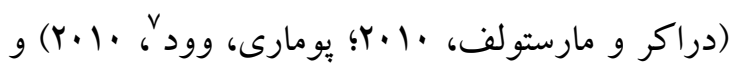

\footnotetext{
.Murray \& zvoch

. Bullying

${ }^{3}$. Olweus

${ }^{4}$. Nontraditional bullying

${ }^{5}$.Cyberbullying

6. Patchin, Hinduja; Haw, Shapka, Hymel, Olspn, Waterhouse;

Kowalski, Morgan \& Limber

7. Drauker \& Martsolf; Pomari, Wood
} 
در حسادت در روابط نزديك آشكار مىشود (داتون،

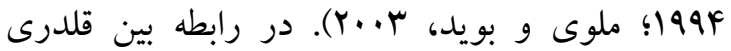
سايبرى با فرزند يرورى ادراكشده و ويز كىهاى شخصيت مرزى يكك متغير ميانجى به نام همدلى وجود بـ برد

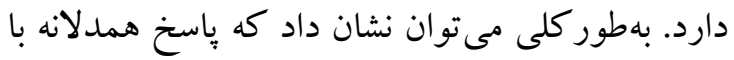
رفتارهاى جامعه پِند رابطه مثبت دارد و با قلدرى

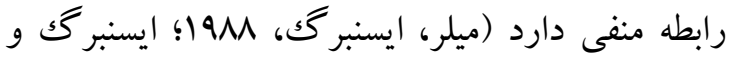

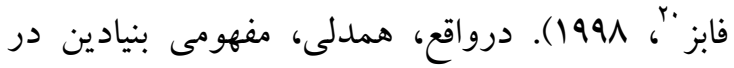
علوم روانشناختى است كه روانشناسان شناختى و روان يويايى بر فرآيندهاى روانشناختى آن متمر كز بوده و

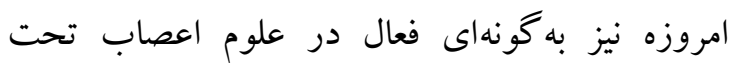

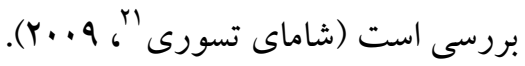

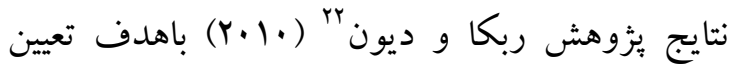

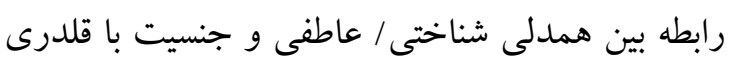

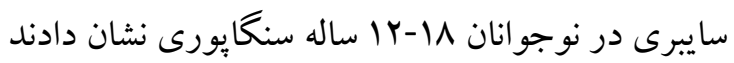
كه همدلى عاطفى/شناختى پِايين در هر دو جنسيت باعث مىشود كه افراد در قلدرى سايبرى نمره بالاترى نسبت به كسانى كه همدلى بالاترى از خود نشان مىدهند، كسب كنند. مبتنى بر يافتها، جنين به نظر مىرسد كه عواملى از قبيل شيوههاى فرزند يرورى، اختلال شخصيت مرزى و همدلى هر يكك به شيوههاى مختلف در بروز و ظهور قلدرى سايبرى نقش دارند و با توجه به وجود ابهامات زياد درزمينه.قلدرى سايبرى و نيز يزوهشهاى اندكى در اين زمينه صورت گرفته است، درنتيجه ارائه مدلى براى تعيين قلدرى سايبرى و عوامل تأثير گذار در آن مىتواند در بسيارى از زمينهها راهگشا باشد. به همين علت يزوهش حاضر با موضوع نقش سبككاى فرزند يرورى و اختلال شخصيت

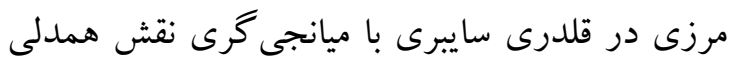

\section{انتخابشده است.}

\footnotetext{
${ }^{20}$. Miller \& Eisenberg; Fabes

${ }^{21}$. shatmay- Tsoory
}

22. Rebecca \& Dion
باسخگگ، حساس، توجه كننده، مشوق، استوار و صميمى بودن والدين نسبت به فرزندانشان است (كرولينك، 19VV). تحقيقات نشان داده است كه

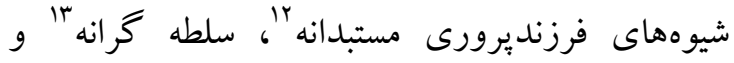

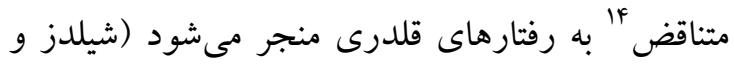

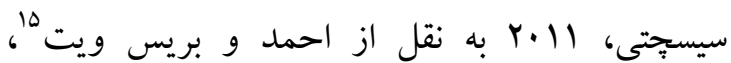

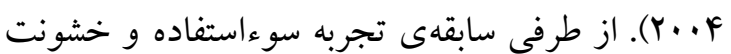
فيزيكى كودكك در محيط خانه با رفتارهاى قلدرى

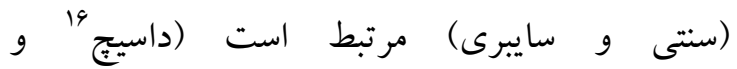

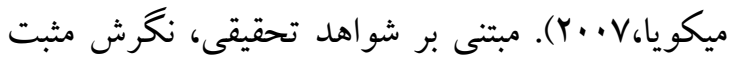
والدين به برخاشخرى، سبك فرزند برورى مستبدانه،

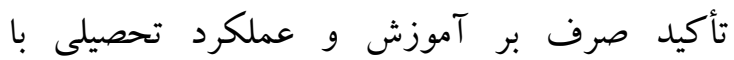

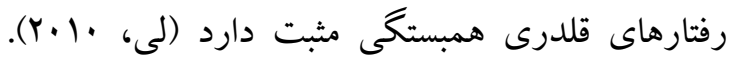
درمجموع، مطالعات دلالت بر شكل گيرى قلدرى در محيطهاى خانوادگىاى دارد كه روابط مبهم و و ناهماهنگك، مشخصه آن است (احمد و بريس ويت، F Y...F قلدرى سايبرى ممكن است بخشى از بازتاب شخصيتى باشد. اختلال شخصيت خودشيفته و اختلال شخصيت ضداجتماعى هر دو با قلدرى سايبرى در

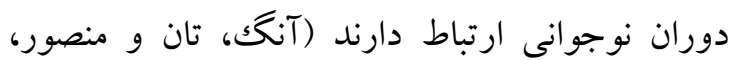

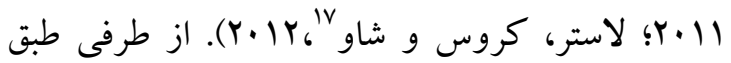
مطالعات انجام شده، اختلال شخصيت مرزى با برخاشخرى فيزيكى، برخاشگرى در روابط عاشقانه همراه هست (داكلاس و داتون، ال+ب؟؛ داتون، 199F،

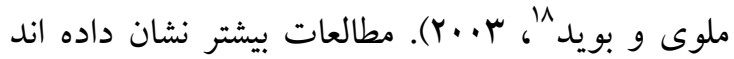
كه اختلال شخصيت مرزى با برخاشگرى رابطه دارد

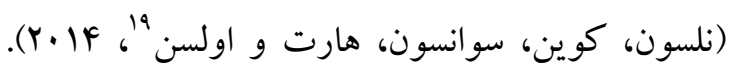
خشم و يرخاشخرى ويز گىهاى شخصيت مرزى اغلب

\footnotetext{
12. authoritarian

13. dominant

14 . inconsistent

15. Shields \& Cicchetti; Ahmed \& Braithwaite

${ }^{16}$.Dussich \& Maekoya

17. Ang, Tan \& Mansor; Lester, Croos \& Shaw

${ }^{18}$. Douglas \& Dutton; Meloy \& Boyd

19. Nelson, Coyne, Swanson, Hart \& Olsen
} 


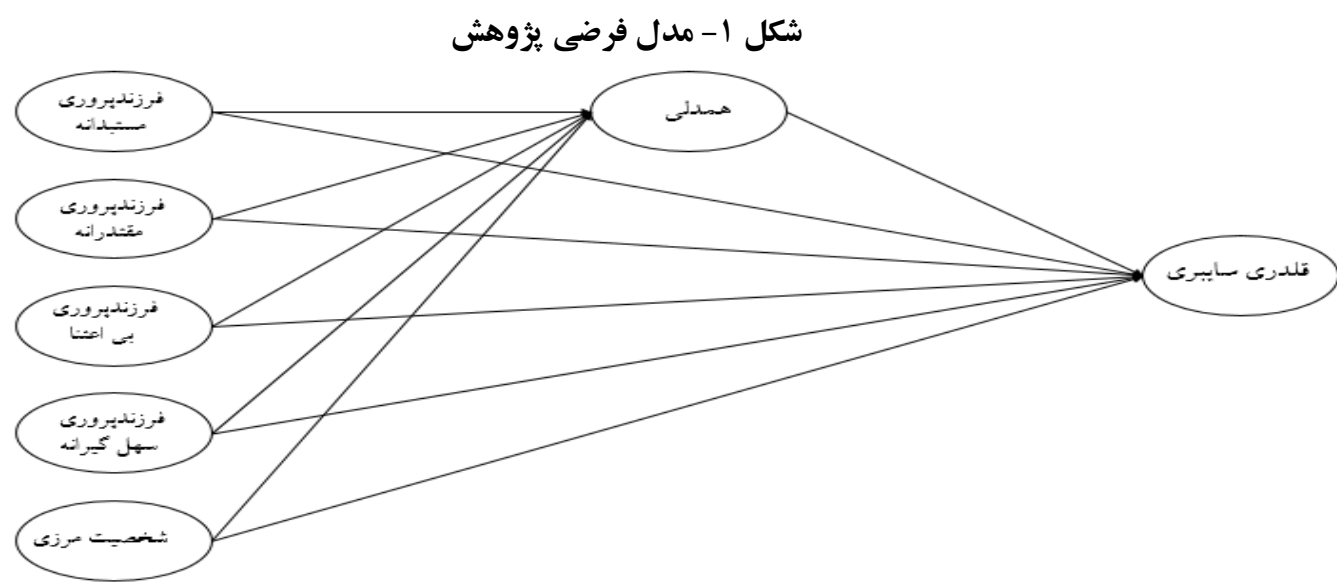

مقياس سبككهاى فززند برورى ادراكتشله " (FSQ)

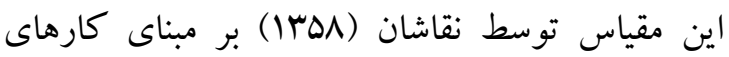
شفر (1990؛ به نقل از حسين جارى، 914|) تهيه شده و داراى VV ماده است. ضريب وِايايى يرسشنامه توسط

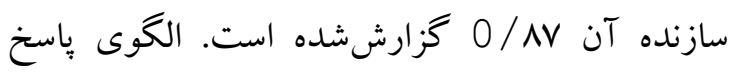
دهى به اين مقياس، ه گزينهاى و بهصورت مقياس درجهبندى ليكرت و داراى دو بعد محبت و كنترل

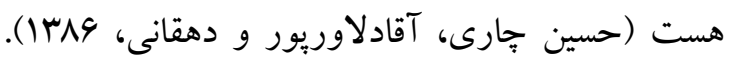
در بعد محبت - طرد نمرات افرادى كه برابر يا بالاتر از ميانگين است افرادىاند كه محبت زيادى دريافت مى كردهاند و در بعد كنترل-آزادى افرادى كه برابر يا بالاتر از ميانگين نمره آورده باشند افرادىاند كه بر برد آنها كنترل بالايى اعمالشده است؛ بنابر اين براى تعيين جهار سبك فرزند يرورى ابتدا ميانگين هر يكك از ابعاد، جدا محاسبه مىشود و بر اساس نمرات بهدست آمده، جهار سبك با مشخصات، مقتدرانه (كنترل بالا- محبت بالا)، سهل گير انه (كنترل پِيين - محبت بالا) و مسامحه كارر (كنترل پايين - محبت پيايين) به دست مى آيد.

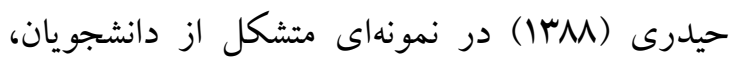
همسانى درونى اين يرسشنامه را براى كنترل-آزادى

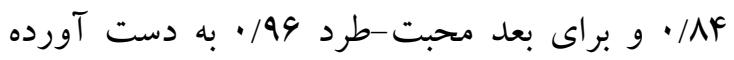

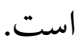

مطالعه حاضر با توجه به اهداف تحقيق، از نوع همبستخى و با توجه به روش جمع آورى دادهها از نوع تحقيقات توصيفى هست. جامعه آمارى يزوهش حاضر را كليهى دانش آموزان پِر پايه سوم متوسطه مدارس دولتى ناحيه F آموزشويرورش شهرستان تبريز تشكيل مىداد كه در سال \$و-QD مشغول تحصيل بودند كه بنابر آمار موجود تعداد كل آنها برابر با سماد دها بود. معيارهاى ورود به مطالعه عبارت بودند از: دانش آموز

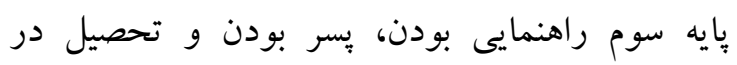
مدرسه دولتى. از جامعه موردمطالعه مطابق با جدول بر آورد حجم نمونه مور گان، تعداد هـr انتخاب شد.

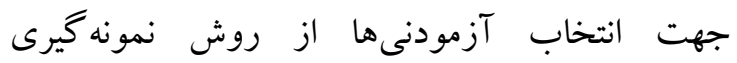
خوشهاى جندمرحلهاى استفاده خواهد شد. بدين نحو

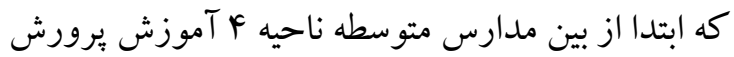

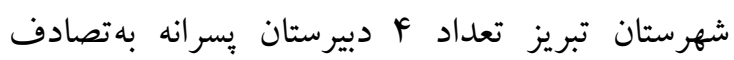

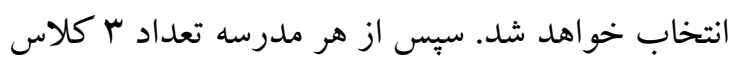
انتخاب خواهد شد و كلئ دانش آموزان موجود در اين كلاسها به عنوان نمونه نهايى در نظر كرفته شد. بعد از كسب رضايت، شركت كنند گان به برسشنامهاى زير

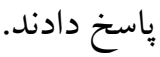


نهايى تنظيم گرديد. اين برسشنامه از سرى برسشنامه-

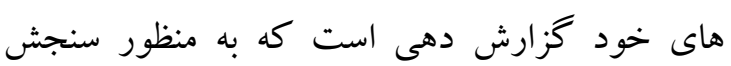
قلدرى / قربانى سايبرى و قلدر / قربانى سنتى توسط

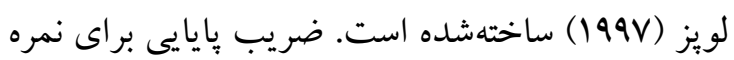

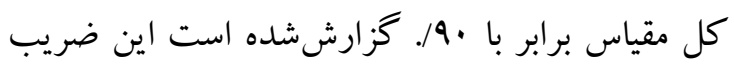
با اجراى رو نمونه YrN/9 نفرى از دانش آموزان ياى هشتم بهدست آمده است، اين ضريب براى خرده

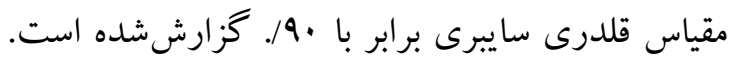

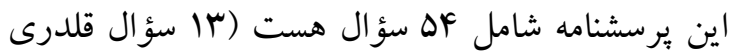
سنتى، سا سؤال قربانى شدن سنتى، عا سؤال قلدرى سايبرى و flf سؤال در مورد قربانى سايبرى) كه باسخدهى سؤالات در طيف ليكرت 9 درجه داى از (هر گز = ا، يكك يا دوبار = r، يكك يا دو بار در هفته

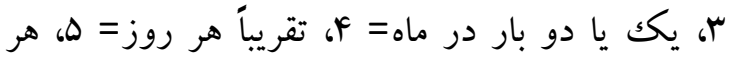
روز= 9) تنظيم شده است. ضريب آلفاى كرانباخ rه/ • كزارش شده است (لويز، 1997، به نقل از كميفيلد،

$(Y \cdots \Lambda$

مقياس همدلى بهر (EQ): اين آزمون كه براى ارزيابى همدلى مورداستفاده قرار گرفت، توسط بارون كوهن و

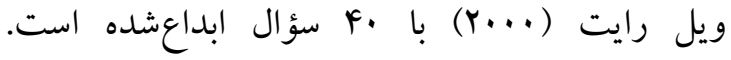
باسخدهى به سؤ الها در قالب طيف ب درجهاى از كاملاً موافق (Y) كمى مو افقم (1) و برخى سؤ الها بهصورت

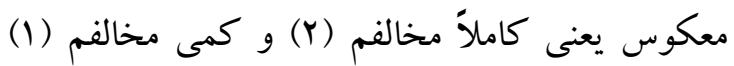
است. نمره بالا در اين آزمون، نشاندهنده توانايى خوب همدلى است. ضريب پايايى براى نمره كل مقياس همدلى بهر VN/ • است. اين ضريب براى خرده

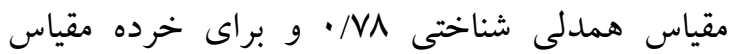

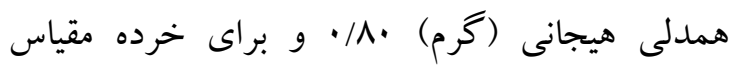
مهارتهاى اجتماعى \$ه/ • بود. همجنين، بايايى مقياس همدلى بهر با استفاده از روش همسانى درونى (آلفاى كرونباخ) را نيز محاسبه كرده است. ضريب آلفاى كرونباخ براى اين مقياس معادل با NV9/ • بود.
مقياس شخصيت مرزى (STB): اين مقياس به منظور سنجش الكوهاى شخصيت مرزى در تحقيقات غير بالينى ساختهده است و شامل YF ماده مىباشد كه به صورت بلى اخير جواب داده مىشود، جواب بلى نمره

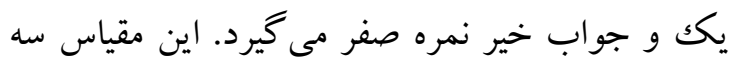
عامل دارد: عامل ناميدى، عامل تكانش گرى و و عامل علائم تجزيهاى و وِارانوييدى وابسته به تنيدگى.

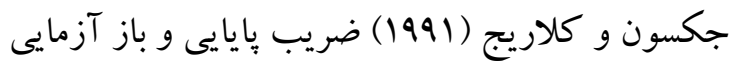

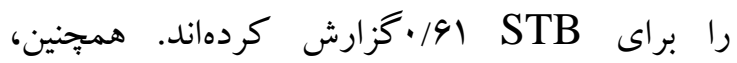

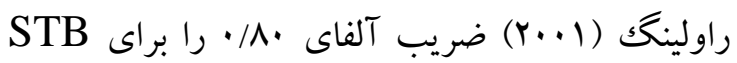
كزارش كردهاند. تحقيقى كه هم توسط شانكار (1991)

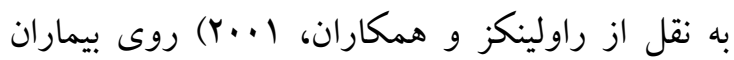
بالينى كه تشخيص اختلال شخصيت مرزى داشتند انجام گرفته، روائى افتراقى و روائى سازه STB راتئي تأييد

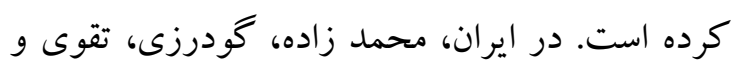
ملازاده (FAF) ضريب بايايى باز آزمايى در فاصله هفته را براى كل مقياس AF STB/A • و براى خرده مقياسهاى ناميدى، تكانش گرى و علائم تجزيهاى و

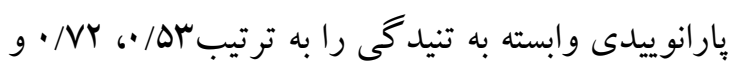

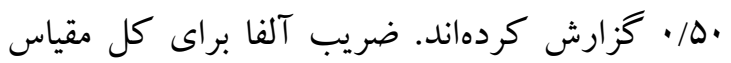
/VV

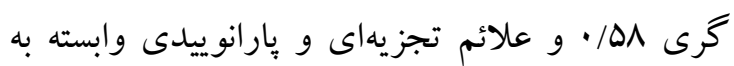

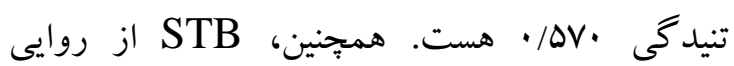
(عاملى و افتراقى) مطلوبى در ايران برخوردار است. يرسشنامه قلدرى سايبرى (CB): در اين بزوهش براى سنجش قلدرى سايبرى از يرسشنامه لويز مايز (199V)

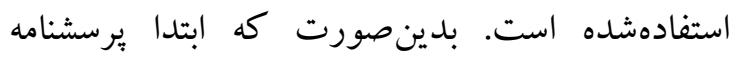

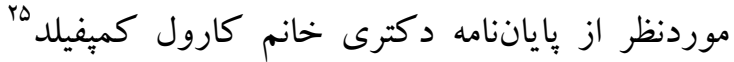
(Y..人) ترجمه و در نهايت با بازنخرى مجدد استاد راهنما فرم

\footnotetext{
${ }^{24}$. Lopez

${ }^{25}$.Carroll Campfield
} 
در حد مطلوب (كوجگكتر از هـ/(RMSEA) قرار دارد. ب) نسبت X Xر df در حد مد مطلوب (كوجگكتر از هـ/•) واقعشده است و اين نسبت در سطح آلفاى كوجككتر از ه./• معنىدار است. ج) شاخص نيكويى برازش (GFI) و شاخص برازش هنجار شده (CFI) و شاخص توكر - لو ييس (TLI)

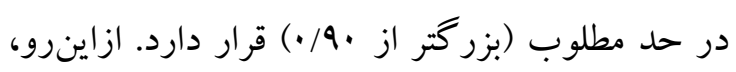

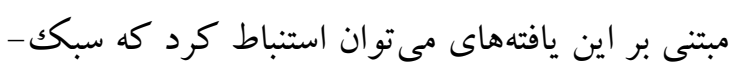
هاى فرزند برورى ادراككشده و نشانهاى شخئ شخصيت مرزى بهواسطه همدلى قادرند در قالب روابط ساختارى تغييرات قلدرى سايبرى را بهطور معنىدار تبيين كنند.

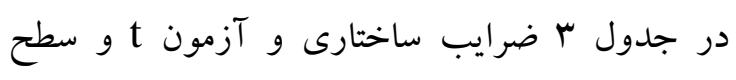
معنىدارى متغيرها آورده شده است كه نشان مىدهد اختلال شخصيت مرزى، همدلى هايين، سبككهاى

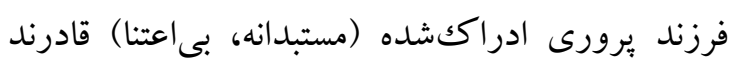

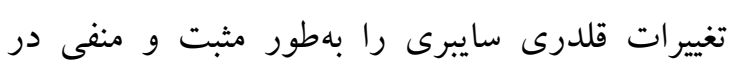
سطح (ه/ (p) ) تبيين كنند. ماتريس كوواريانس بين متغيرهاى يُزوهش، به همراه ميانگين و انحراف معيار آنها در جدول إندين ديده مىشود. بر اساس اطلاعات مندرج در جدول، ميانگين

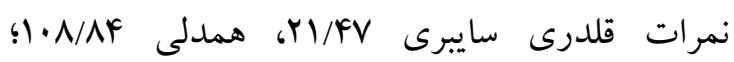

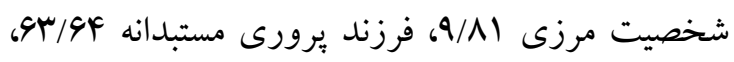

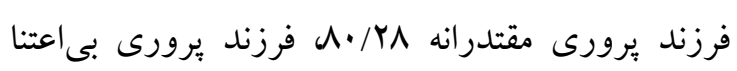
ه FY/YV همجنين مندرجات جدول ا نشان مىدهد كه بين متغيرها يزوهش هم تغييرى مثبت و منفى قابل ملاحظهاى

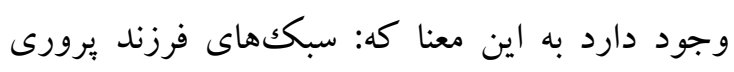
ادراكششه و نشانهاى شخصيت مرزى به بهواسطه همدلى قادرند در قالب روابط ساختارى تغييرات قلدرى سايبرى را بهصورت مثبت و منفى تبيين كنند.

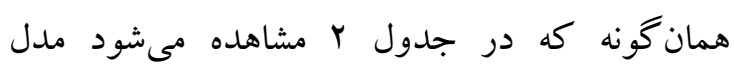
اندازهيرى شده با مدل نظرى برازش مطله مدول جر اكه الف) مقدار ريشه ميانخين مجذور خطاى تقريب

جدول شماره ا - ماتريس كوواريانس، ميانتين و انحراف استاندارد بين متغيرها

\begin{tabular}{|c|c|c|c|c|c|c|c|c|}
\hline ميانكين (انحراف استاندارد) & فرزنديرورى & فرزنديرورى بى اعتنا & فرزنديرورى مقتدرانه & فرزنديرورى مستبدانه & شخصيت & همدلى & قايبرى & متغير ها \\
\hline$(11 / 99) r 1 / 1 V$ & & & & & & & $F / 9 r$ & سلدرى \\
\hline$(1 \cdot / \Lambda \cdot)) \cdot \Lambda / \Lambda F$ & & & & & & $r / V F$ & $-Y / V Y$ & همدلى \\
\hline$(F / V I) q / \Lambda I$ & & & & & $F / I r$ & $-Y / Y Y$ & $r / 91$ & شخصيت \\
\hline$(14 / 99) 94 / 94$ & & & & $r / 90$ & $1 / 19$ & $-Y / / F$ & $r / Y I$ & فرزنديرورى \\
\hline$(I V / 9 \cdot) \Lambda \cdot / T \Lambda$ & & & $r / 10$ & $-1 / 11$ & $-Y / Y)$ & $r / D)$ & $-1 / 29$ & فرزتدريرورى \\
\hline$(I T / T V) F Y / T V$ & & T/VV & $-1 / 99$ & $-Y / I V$ & $r / .9$ & $-1 / 09$ & $1 / 41$ & فر زنديرورى اعتنا \\
\hline$(1 \cdot / r \Delta) r g / A$. & $T / F \Delta$ &.$/ 91$ & $-1 / \cdot 1$ & $-I / A r$ & $1 / r \Delta$ & $1 / T V$ & $1 / 19$ & فرزنديرورى \\
\hline
\end{tabular}

جدول r- شاخصهاى برازش مدل اندازهكيرى 


\begin{tabular}{|c|c|c|c|c|c|c|c|c|c|}
\hline TLI & NFI & CFI & AGFI & GFI & $\mathbf{P}$ & $\mathrm{X}^{2} / \mathrm{df}$ & Df & $\mathbf{X}^{2}$ & RMSEA \\
\hline.$/ 9 r$ &.$/ 9 r$ &.$/ 90$ & ש & $\cdot / 9 F$ &.$/ \cdots 1$ & $r$ & $|F|$ & FYT & .1 .4 \\
\hline
\end{tabular}

\begin{tabular}{|c|c|c|c|c|}
\hline \multicolumn{5}{|c|}{ جدول r- ضرايب ساختارى و آزمون t جهت بررسى اثرات مستقيم } \\
\hline سطح معنى دارى & $\mathbf{T}$ & 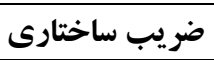 & متغير وابسته & متغير مستقل \\
\hline $\mathrm{p}<0 / 05$ & $F / Y G$ & ו ו ו & قلدرى سايبرى & شخصيت مرزى \\
\hline $\mathrm{p}<0 / 05$ & $-9 / 19$ & $-\cdot / \Delta V$ & قلدرى سايبرى & همدلى \\
\hline $\mathrm{p}<0 / 05$ & $r / v 1$ & $\cdot / r \Delta$ & 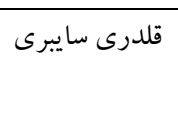 & فرزند يرورى مستبدانه \\
\hline $\mathrm{p}<0 / 05$ & $-r / I r$ & $-\mid M_{1}$ & قلدرى سايبرى & فرزند يرورى \\
\hline $\mathrm{p}<0 / 05$ & $r / \Delta 1$ &.$/ 1 \mathrm{~V}$ & قلدرى سايبرى & فرزند يرورى \\
\hline $\mathrm{p}<0 / 05$ & $1 / 94$ &.$/ 11$ & 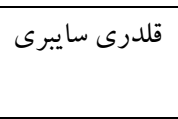 & فرزند يرورى \\
\hline
\end{tabular}

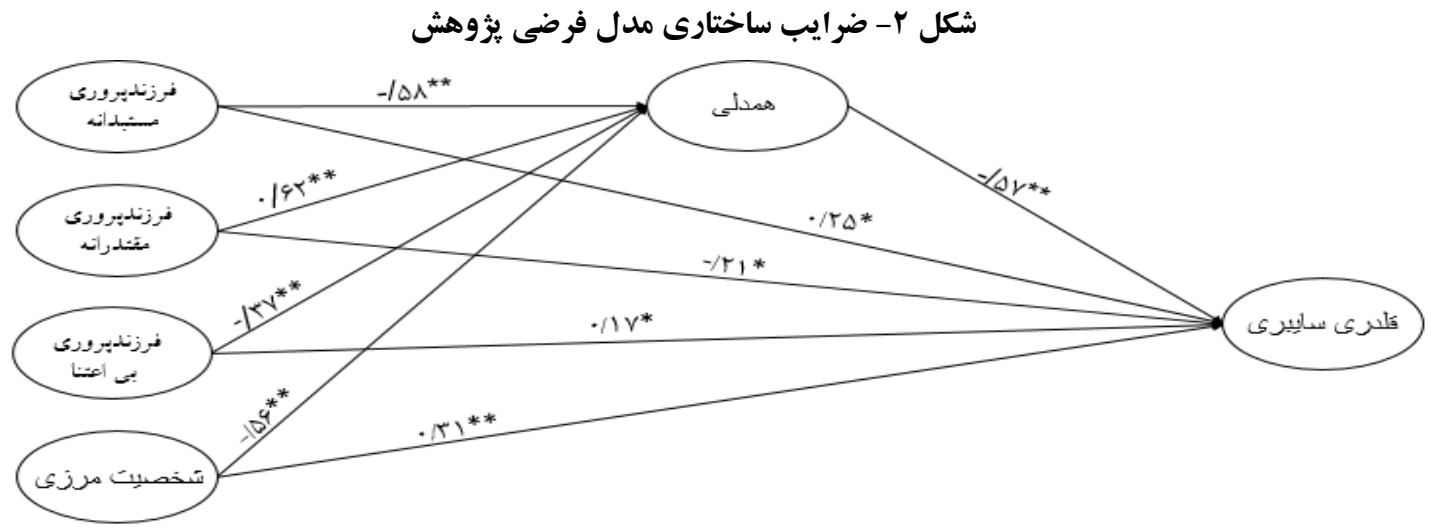

هستند، اين افراد ممكن است از روشهاى مختلف بحث و نتيجه كيرى

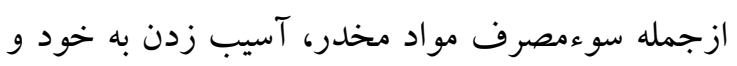

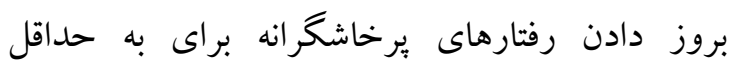

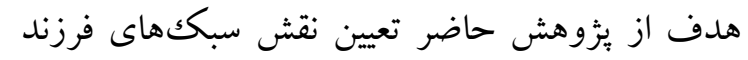

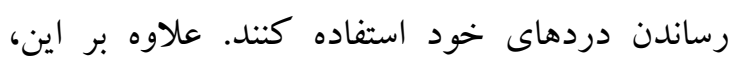
يرورى ادراككشده و اختلال شخصيت مرزى در مىتوان از مدل يرخاشگرى عمومى استفاده نمود قلدرى سايبرى با ميانجى گرى نقش همدلى بود. نتايج

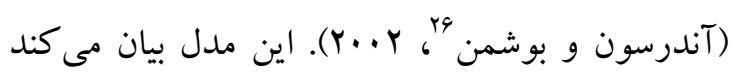
يزوهش نشان داد كه بين نشانهاى اختلال شخصيت لئي مرزى و قلدرى سايبرى رابطه مثبت وجود دارد. در كه افراد محرك كهايى را كه در محيط اجتماعى، ميان

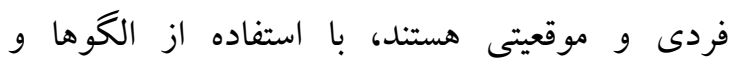
تبيين اين يافته و در رابطهى نشانهاى شخصيت مرزى با قلدرى و برخاشخرى مىتوان كفت كه اختلال

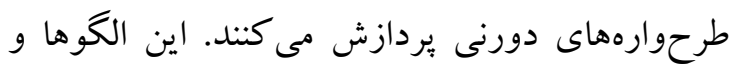
طرحوارههاى درونى مىتواند تحت تأثير حالتهاى

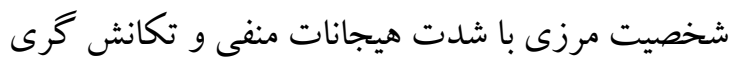
و افكار خودكشى رابطه دارد و افراد مبتلابه اختلال شخصيت مرزى به دنبال فرار از احساسات دردناك وكى 
را به كمك كردن به ديخران ترغيب مى كند (بارون-

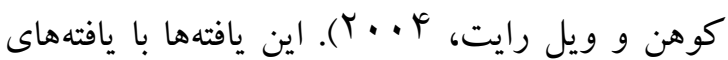

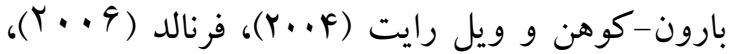

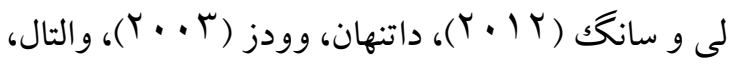

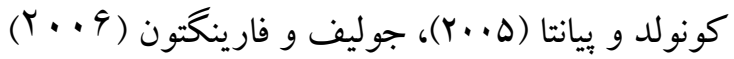

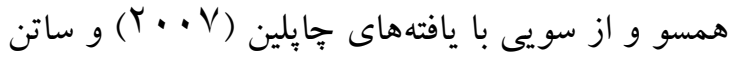

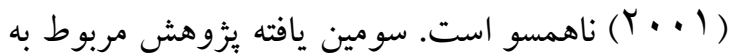
سبكهاى فرزند يرورى هست كه نتايج نشان داد شيوههاى فرزند يرورى ادراككشه مستبدانه و بىاعتنا با قلدرى سايبرى رابطه مثبت دارند و شيوههاى فرزند يرورى ادراككشده مقتدرانه با قلدرى سايبرى رابطه

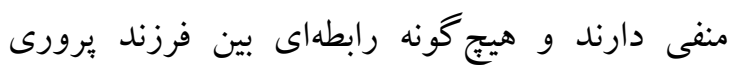
ادراكشده سهل گيرانه و قلدرى سايبرى يافت نشد.

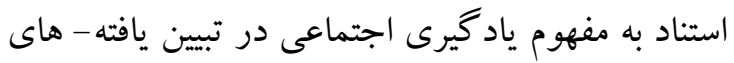

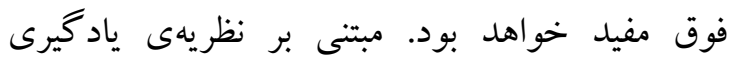

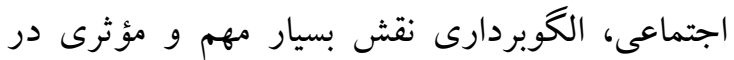
ياد گيرى مهارتهاى جديد و اجتماعى شدن انسانها

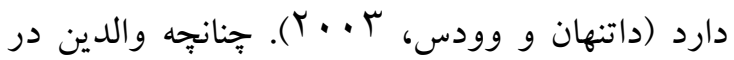
تربيت فرزندان خود سهل گيرى يا سخت گيرى افراطى ودان ودئ داشته و يا نسبت به نيازهاى فرزندان بىتوجه باشند، يا تعاملات خانوادگى مبتنى بر استفاده از الخوهاى

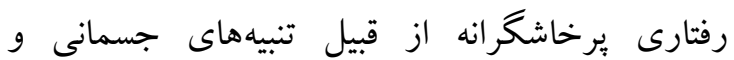
برونريزى عواطف خشونتآميز باشد، احتمال بروز قلدرى در ميان فرزندان وجود خواهد داشت. درواقع، والدين بهعنوان يكك الكوى ارتباطى و آموزشى رفتارهاى اجتماعى فرزندان خود را شكل مىدهند. مطالعات به آشكار نشان داده است كه قلدران واقعى در خانو ادههايى برورش يافتهاند كه بدر خانواده يك قلدر

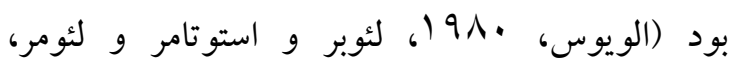

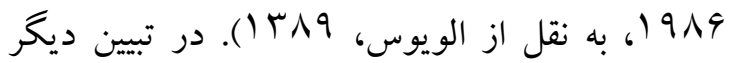

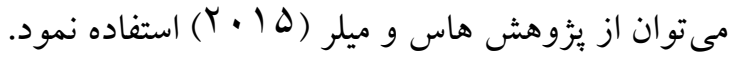
بهمنظور انجام اين يُوهش، ·^ نفر به برسشنامهاى به
درونى مانند حالتهاى عاطفى، سطح انخيختكى و

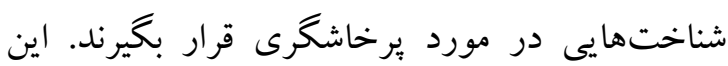
فعلوانفعال بين محرككها و حالتهاى درونى افراد، بردازش محرك و ويامد رفتار كه آيا برخاشگ انه است يا نه را تحت تأثير قرار مىدهد. استفاده از مدل يرخاشخرى عمومى باهدف تبيين رابطه بين BPD و قلدرى سايبرى (رفتارهاى برخاشگرانه ديخر) در اين بخش بيانشده است. براى مثال، افراد مبتلا به

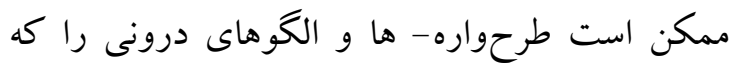
بيشتر طرفدار برخاشگرى و بذيرش رفتار برخاشگر انه

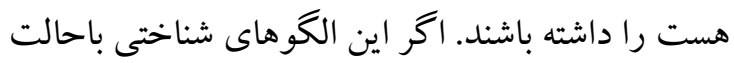
عاطفى مثل حسادت بالا و همدلى بايين تر كيب شوند، بهاحتمالزياد محرك خارجى را بهعنوان تهديد يردازش كنند و به موقعيتهاى اجتماعى با شدت

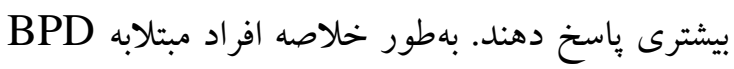
كه حسادت بالا و همدلى پايينترى دارند، بيشتر

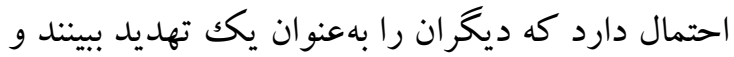

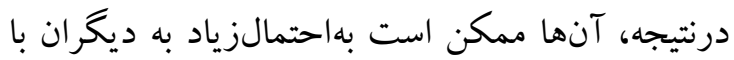
استفاده از برخاشگرى و قلدرى سايبرى در طول دورهى نوجوانى ياسخ دهند. اين يافته با يافتهاى

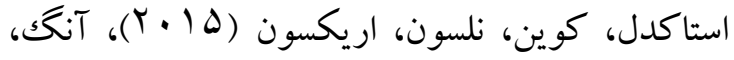

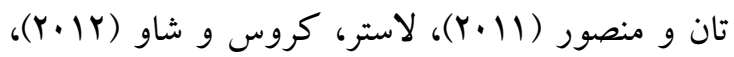

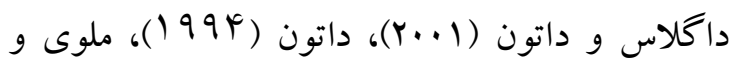

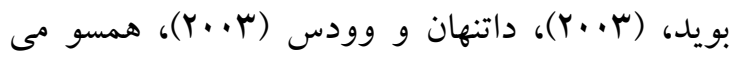
باشد. علاوه به راين همدلى قادر است بهطور منفى رفتارهاى قلدرى سايبرى را بيشبينى كند. در تبيين اين يافتها مى توان عنوان كرد كه همدلى بهعنوان سازه

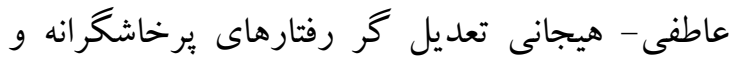
قلدرى در جامعه است. همدلى احساس قدرتمندى است كه با برخاشخرى و رفتارهاى ضداجتماعى رابطه منفى دارد و مانع بروز رفتارهاى خشن مىشود و امكان تعامل مؤثر در محيط اجتماعى رابه افراد داده و آنها مارديا 


$$
\begin{aligned}
& \text { يثزوهشى نسبتاً جديدى نياز است؛ باوجود اين يافتهاى } \\
& \text { اين يزوهش بر نقش بالقوه سبكهاى فرزند يرورى } \\
& \text { ادراككشده، اختلال شخصيت مرزى و همدلى بهعنوان } \\
& \text { ريسك فكتورهاى قلدرى سايبرى صحه گذاشت. }
\end{aligned}
$$$$
\text { تشكر و قدردانى }
$$

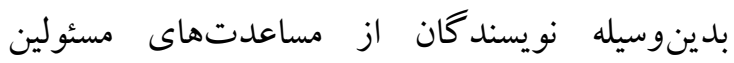
آموزشوبرورش شهرستان تبريز تقدير و و تشكر مىنمايند. همجنين، از تمامى دانش آموزانى كه در اين

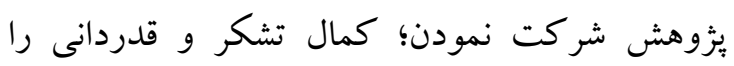

$$
\text { دارند. }
$$

\section{References}

Ahmed, E. and Braithwaite, V. (2004). "What, me ashamed?" Shame management and school bullying. Joumal of Research in Crime and delinquency, 41: 269-294.

Anderson, C. A., \& Bushman, B. J. (2002). Human aggression. Annual Reviews of Psychology, 53, 27-51.

Ang, R.P., Tan, K.-A. and Mansor, A.T. (2011). Normative beliefs about aggression as a mediator of narcissistic exploitativeness and cyberbullying. Joumal of Interpersonal Violence,26, 2619-2634.

Anthony Efobil \& Chinyelu Nwokolo, (2014). Relationship between Parenting Styles and Tendency to Bullying Behaviour among Adolescents Joumal of Education \& Human Development 1,pp. 507-521.

Baron-Cohen,S. and Wheelwright,S.(204).The empathy quotient: an investigation of adults with Asperger syndrome or high functioning autism and normal sex differences. Journal of autism and developmental disorders 34: 163-175.

Carroll Campfield, Delia.(2008). Cyber Bullying and victimization: psychosocial characteristics of bullies, victims, and bully/victims, University of Montana, Missoula, Montana, Clinical Psychology.
نام برسشنامه ه عامل شخصيت مرزى ياسخ دادند تا مشخص شود هر يكك تا جه اندازه داراى صفات

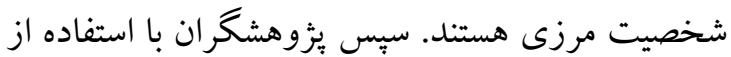
تصويربردارى تشديد مغناطيسى كاركردى، فعاليت مغزى شر كت كنند گان را اندازهيرى كردند. در طول انجام تصويربردارى FMRI از شركت كنند مان خواسته شد تا فعاليتى مرتبط با همدلى انجام دهند. بدين ترتيب كه از توانايى خود استفاده كنند و به يكك

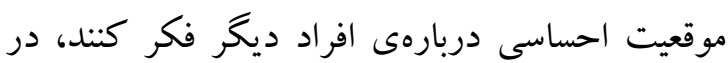
حالى كه FMRI نيز به طور همزمان فعاليت مغزى

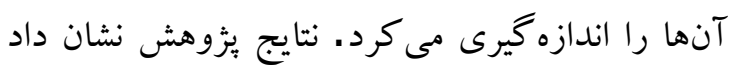
فعاليت نواحى مغزى مرتبط با همدلى در افراد مبتلا به صفات BPD كاهش مىيابد. اين كاهش فعاليت نشان مىدهد افراد مبتلا به BPD حداقل در مقايسه با افرادى كه كمتر دجار صفات BPD هستند،

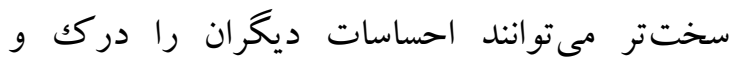
بيشبينى كنند. هاس و ميلر توانستد ارتباط بين كرفتن نمرهى بالا در نشانهاى اختلال شخصيت مرزى را با سيا كاهش فعاليت عصبى در دو بخش مغز، اتصال گيجگاهى و شيار فوق گيجگاهى مشخص كند. اين دو ناحيهى مغزى در فرايند همدلى، نقش بسيار مهمى ايفا

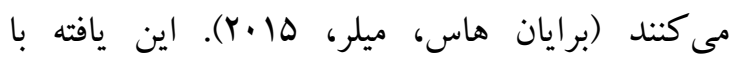

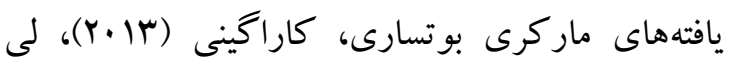

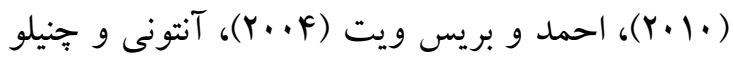

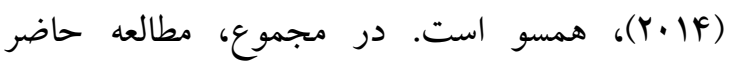
اطلاعات ارزشمندى براى فهم قلدرى سايبرى و ارتباط آن با سه عامل يعنى سبك هاى فرزنديرورى برى ادراككشده، اختلال شخصيت مرزى و همدلى فراهم آورد. باوجوداينكه مطالعه بيشترى در اين عرصه

Chaplin, H. (2007). bullying behavior and situational element. Juurnal of child behavior, 11, 119-129.

Douglas, K.S.and Dutton, D.G. (2001). Assesssing the link between stalking and domestic violence. Aggression and Violent Behavior, 6: 519-546. 
Draucker,C.B.,\&Martsolf, D.S.(2010).The role of electronic communication technology in adolescent dating violence. Joumal of Child and Adolescent Psychiatric Nursing, 23, 133-142.

Dussich, J P. and Maekoya, C. (2007). Physical child harm and bullying-related behaviors: A comparative study in Japan, South Africa, and the United States. Intemational Joumal of offender Therapy and Comparative Criminology.

Dutton, D. G. (1994). Behavioral and affective correlates of borderline personality organization in wife assaulters. International Journal of Law and Psychiatry, 17: 265-277.

Eisenberg, N., \& Fabes,F.(1998).prosocial development. in $\mathrm{n}$. eisenberg (ed), handbook of child psychology, volume 3: social, emotional and personaliyt development(5 end, pp. 701-778).

Femald, K.(2006). Empathy and conduct disorders. Journal of Abnormal Psychology,18,321-339.

Grolnick, W. S., Deci, E. L., \& Ryan, R. M. (1977). Internalization within the family: The selfdetermination theory

Has, B. w. and Miller, J. D. (2015). Borderline personality traits and brain activity during emotional perspective pndovnsdv qeknoqegm eqrgnoqerg qeergibnqobgr.

Jolliffe, D. and Farrington, D. P. (2006).Examining the relationship between low empathy and bullying. Aggressiv behavior, 32, 1-11.

Kowalski,R.M.,Morgan,Ch.A.\&Limber,S.P.(2012).Trad itional bullyingas a potential waming sing of cyberbullying. School Psychology International Journal, 33(5), 505-519.

Law, D.M. Shapka, J.D., Hymel, Sh., Olson, B.f. \& Waterhouse, T. (2012). The changing face of bullying: An Empirical comparison between traditional and intemet bullying and victimization.Computer in Human behavior Behavior, 28, 226-232.

Lee, C.-H. (2010).Personal and interpersonal comelates of bullying behaviors among Korean middle school students. Joumal of interpersonal violence. 33(4), 323-330.

Lee, C.H. and and Song, J. (2012). Functions of parental involvement and effects of school climate on bullying behaviors among South Korean middle school students. Joumal of interpersonal violence: 1-28.
Lester, L., Cross, D. and Shaw, T. (2012). Problem behaviours, traditional bullying and cyber bullying among Adolescents: longitudinal analyses. Emotional and behavioural difficulties, 17: 435-447

Meloy, J. R. \& Boyd, C.(2003). Female Stalkers and Their Victims. Joumal of American Academy of Psychiatry and the Law, 31, 211-219.

Miller, P. A. and Eisenberg, N. (1988). The relation of empathy to aggressive and externalizing/antisocial behavior Psychological bulletion, 103:324.

Murray, Ch., Zvoch, K. (2011). Teacher- student Relationships among Behaviorally Atrisk African American Youth From Law- Income Backgrounds: Student Perceptions, Teacher Perceotions, and Socioemotional Adjustment Correlayes. Emotional and Behavioral Disorders. 19(1), 41-54.

Nelson, D. A., Coyne, S. M., Swanson, S. M., Hart, C. H.,\& Olsen,J. A. (2014). Parenting, relational aggression, and borderline personality features: Associations over time in a Russian longitudinal sample. Development and Psychopathology, 26, 773-787.

Olweus, D. (1993). Bullying at school: What we know and what we can do._Oxford: Blackwell.

Patchin, J.W., \& Hinduja, S. (2011). Traditional and nontraditional bullying among youth: A Test of General Strain Theory. Youth \& Society, 43(2), 727-751.

perspective. In J. E. Grusec \& L. Kuczynski (Eds.), Parenting and children's internalization of values: $A$ handbook of contemporary theory (pp. 135161). New York: Wiley.

Pomari, C. D., \& Wood, J. (2010). Peer and cyber aggression in secondary school students: The role of moral disengagement, hostile attribution bias, and outcome expectancies. Aggressive Behavior, 36, 81-94.

Rebecca P. Ang • Dion H. Goh. (2010). Cyber bullying Among Adolescents: The Role of Affective and Cognitive Empathy, and Gender. Child PsychiatryHum (2010) 41:387-397.

Rudasill, K.M., Gallagher, K.C. and White, J.M. (2010). Temperamental attention and activity, classroom emotional support, and academic achievement in third grade. Journal of School Psychology, 48: 113-134. 
Shamay-Tsoory, S.G. (2009).16Empathic Processing: Its Cognitive and Affective Dimensions and Neuroanatomical Basis. The social neuroscience of empathy: 215-232.

Stockdale, L. A., Coyne, S. M., Nelson, D.A. and Erickson, D. H. (2015). Borderline personality disorder features, jealousy, and cyberbullying in adolescence. Personality and Individual Differences, 83: 148-153.

Sutton, J. (2001). Bullies: Thugs or thinlers? The Psychologis, 14(10), 530-534.

Walthall, J.C., Konold, T.R. and Pianta, R. C. (2005). Factor structure of the social skills rating system across child gender and ethnicity. Joumal of Psychoeducational Assessment, 23: 201-215. 